Article

\title{
Antioxidant, Anti-Inflammatory, and Multidrug Resistance Modulation Activity of Silychristin Derivatives
}

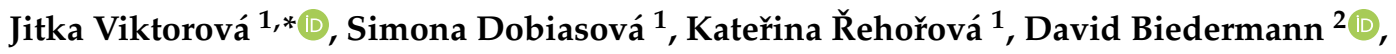 \\ Kristýna Káňová ${ }^{2}$, Karolína Šeborová ${ }^{3,4}$, Radka Václavíková ${ }^{3,4}$, Kateřina Valentová ${ }^{2}$, \\ Tomáš Ruml ${ }^{1}$, Vladimír Křen ${ }^{2} \mathbb{1}$ and Tomáš Macek ${ }^{1}$ \\ 1 Department of Biochemistry and Microbiology, University of Chemistry and Technology Prague, \\ Technická 5, CZ 16628 Prague, Czech Republic \\ 2 Laboratory of Biotransformation, Institute of Microbiology, Czech Academy of Sciences, Vídeňská 1083, \\ CZ 14220 Prague, Czech Republic \\ 3 Toxicogenomics Unit, National Institute of Public Health, Šrobárova 49, CZ 10000 Prague, Czech Republic \\ 4 Laboratory of Pharmacogenomics, Biomedical Center, Faculty of Medicine in Pilsen, Charles University, \\ alej Svobody 1655, CZ 32300 Pilsen, Czech Republic \\ * Correspondence: prokesoj@vscht.cz
}

Received: 27 June 2019; Accepted: 12 August 2019; Published: 14 August 2019

\begin{abstract}
Silychristin A is the second most abundant compound of silymarin. Silymarin complex was previously described as an antioxidant with multidrug resistance modulation activity. Here, the results of a classical biochemical antioxidant assay (ORAC) were compared with a cellular assay evaluating the antioxidant capacity of pure silychristin A and its derivatives (anhydrosilychristin, isosilychristin and 2,3-dehydrosilychristin A). All the tested compounds acted as antioxidants within the cells, but 2,3-dehydro- and anhydro derivatives were almost twice as potent as the other tested compounds. Similar results were obtained in LPS-stimulated macrophages, where 2,3-dehydro- and anhydrosilychristin inhibited NO production nearly twice as efficiently as silychristin A. The inhibition of P-glycoprotein (P-gp) was determined in vitro, and the respective sensitization of doxorubicin-resistant ovarian carcinoma overproducing P-gp was detected. Despite the fact that the inhibition of P-gp was demonstrated in a concentration-dependent manner for each tested compound, the sensitization of the resistant cell line was observed predominantly for silychristin A and 2,3-dehydrosilychristin A. However, anhydrosilychristin and isosilychristin affected the expression of both the P-gp (ABCB1) and $A B C G 2$ genes. This is the first report showing that silychristin $\mathrm{A}$ and its 2,3-dehydro-derivative modulate multidrug resistance by the direct inhibition of $\mathrm{P}$-gp, in contrast to anhydrosilychristin and isosilychristin modulating multidrug resistance by downregulating the expression of the dominant transmembrane efflux pumps.
\end{abstract}

Keywords: Adriamycin; P-glycoprotein; silymarin; silychristin; immunomodulation; $A B C$ superfamily; BCRP; expression profile

\section{Introduction}

Silychristin is the second most abundant flavonolignan in the silymarin complex, which is usually produced by the acetone extraction of Silybum marianum (L.) Gaertn. (milk thistle) fruits [1]. Despite its high content in the silymarin complex and its biological potential, little attention has been paid to this compound, mainly due to its rather difficult separation leads to its co-elution with one of its isomeric flavonolignans, silydianin [1], a problem that has been resolved recently [2] by careful chromatography on LH-20 gel. Natural silychristin is a mixture of two diastereomers 
(silychristin A and B, 95:5). Isosilychristin is a silychristin isomer that mainly occurs in wild milk thistle, while 2,3-dehydrosilychristin is a product of its aerial oxidation [3,4] detectable in silymarin preparations. In contrast, anhydrosilychristin is a dehydrated product obtained by the treatment of silychristin with hydrochloric acid in hot ethanol [1] (Figure 1). The biological potential of these derivatives has been reviewed recently [1].<smiles>COc1cc(C2Oc3cc([C@H]4Oc5cc(O)cc(O)c5C(=O)[C@H]4O)ccc3O[C@@H]2CO)ccc1O</smiles>

silybin A

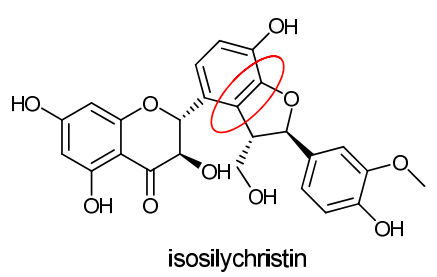

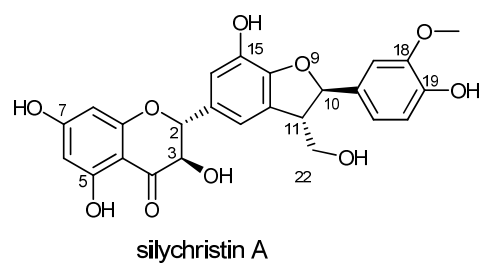

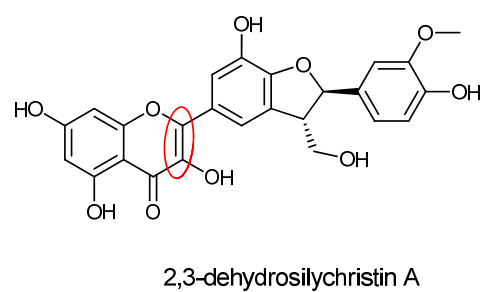

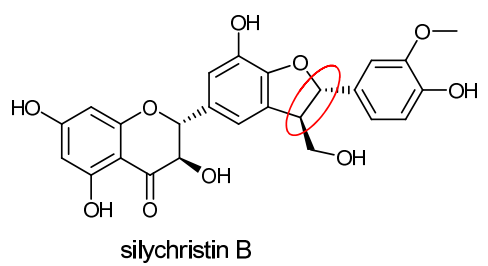

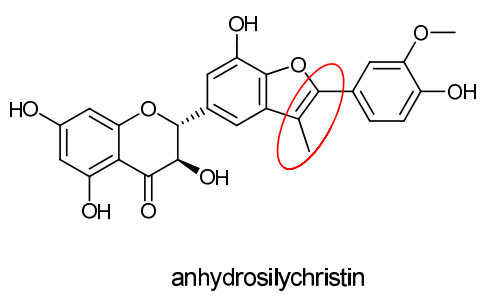

Figure 1. Structure of silychristin diastereomers and derivatives. Major structural differences from silychristin A are highlighted with red ovals. The structure of silybin A is shown for comparison.

As other components of the silymarin complex, silychristin has antioxidant properties. Its potential to scavenge the 2,2-diphenyl-1-picrylhydrazyl (DPPH) radical is nearly $14 \times$ higher than that of silybin (considered "the active component of silymarin") and approximately $1.5 \times$ lower than that of its oxidized derivative 2,3-dehydrosilybin [5,6]. Moreover, silychristin exhibited a higher antioxidant capacity than "traditional" antioxidants such as synthetic phenolic antioxidants: butylated hydroxyanisole (BHA), butylhydroxytoluene (BHT), $\alpha$-tocopherol and trolox [7]. As the first-pass metabolism of polyphenols such as silychristin is usually connected to conjugation [8], its sulfated derivatives were also tested for their antioxidant properties. Although the sulfated metabolite of silychristin was a less potent antioxidant, sulfated 2,3-dehydrosilychristin was more active in FCR (Folin-Ciocalteu reagent reduction) and FRAP (ferric reducing antioxidant power) assays than the parent compound [9].

Besides antioxidant activity, several other biological activities have been reported for silychristin. Silychristin was able to inhibit $\alpha$-glucosidase [10], exhibiting a potential in the treatment of diabetes mellitus type II. Furthermore, silychristin increased insulin secretion and decreased glucose content in induced type I diabetic rats [10] and Mesocestoides vogae larvae [11]. Silychristin also displayed concentration-dependent anti-inflammatory activity [12] and inhibited collagenase much more efficiently than its standard inhibitor 1,10-phenanthroline [5], thus showing a potential application in cosmeceuticals. In a transdermal study, silychristin penetrated into the human skin but did not reach the basolateral side [13]. Both acute cytotoxic and genotoxic doses were higher than $100 \mu \mathrm{M}$ for blood platelets, peripheral blood mononuclear cells, and alveolar basal epithelial cells. Moreover, at these concentrations, silychristin protected mitochondria against spontaneous DNA damage [14]. Moreover, copper and iron chelation was affected by silychristin as well, with possible implications for the absorption of these ions in the gastrointestinal tract [15].

The antithrombotic activity was described in detail by the group of Bijak et al.; silychristin inhibited ADP-induced blood platelet activation via the G protein-coupled receptor P2Y12. This blockade could potentially reduce the peripheral artery disease, myocardial infarction, ischemic stroke, and vascular death [16]. Similarly, silychristin inhibited collagen-induced blood platelet activation, the usual response to tissue injury, which can lead to thrombotic events in cases of overactivation [17].

In addition to $\alpha$-glucosidase, silychristin has also been described as an inhibitor of human carbonic anhydrase. This enzyme is responsible for maintaining the acid-base balance and for the transport 
of carbon dioxide. Inhibitors of this enzyme have several clinical applications, as a diuretic and antiepileptic, and in the treatment of gastric and duodenal ulcers, but their primary use is in the treatment of glaucoma [18].

In this study, the antioxidant, anti-inflammatory, and MDR modulation activities of silychristin are compared to its natural and synthetic derivatives. We demonstrate that 2,3-dehydrosilychristin is the most promising antioxidant and anti-inflammatory compound. Moreover, we describe the ability of silychristin and its 2,3-dehydro- derivative to inhibit P-glycoprotein (P-gp) and thus reverse the doxorubicin-resistance phenotype in resistant human ovarian carcinoma. In contrast to this direct inhibition of P-gp, we suggest that anhydrosilychristin and isosilychristin modulates the multidrug resistance by downregulating the expression of the dominant transmembrane efflux pumps.

\section{Materials and Methods}

\subsection{Analytical Standards and Chemicals}

We used 2,2'-azo-bis-(2-methylpropionamidine) dihydrochloride (AAPH, Sigma-Aldrich, St. Louis, MO, USA); $2^{\prime}, 7^{\prime}$-dichlorofluorescin diacetate (DCFH-DA, Sigma-Aldrich); 100 $\times$ antibiotic antimycotic solution (Sigma-Aldrich); fetal bovine serum (FBS, Sigma-Aldrich); Eagle's minimum essential medium (EMEM, Sigma-Aldrich); lipopolysaccharides from Escherichia coli O111:B4 (LPS, Sigma-Aldrich); fluorescein (Sigma-Aldrich); Griess reagent modified (Sigma-Aldrich); resazurin sodium salt (Sigma-Aldrich); Pgp-Glo Assay System (Promega, Madison, WI, USA); doxorubicin hydrochloride (sold under the trade name Adriamycin, Sigma-Aldrich); Trizol Reagent (Thermo Fisher Scientific, Walham, MA, USA); L-glutamine solution (Sigma-Aldrich); trypsin-EDTA solution (Sigma-Aldrich); Essential Medium Eagle no phenol red (MEM, Sigma-Aldrich); and Dulbecco's Modified Eagle's medium—-high glucose (DMEM, Sigma-Aldrich). Silybin was isolated from silymarin by its quick suspension in methanol and filtration, yielding solid silybin A+B. Silybin diastereomers were isolated as described previously [19] to obtain silybin A (99\%) and silybin B. Briefly, silybin diastereomers are chemoenzymatically resolved by immobilized lipase B from Candida antarctica (Novozyme 435, Novo-Nordisk, Copenhagen, Denmark). A series of consecutive acetylations and solvolyses was used. Silychristin A ( $96.4 \%$, containing 3.6\% of silychristin B) was isolated from silymarin by Sephadex LH-20 chromatography as described in [2]. 2,3-Dehydrosilychristin A ( $91.2 \%$, containing $8.8 \%$ of silychristin B), isosilychristin (95.8\%) and anhydrosilychristin (92\%, containing ca. $4 \%$ of silychristin A) were prepared as described by Biedermann et al. [1]. Briefly, 2,3-dehydrosilychristin A was synthesized by oxidation of silychristin with gaseous oxygen in DMSO in the presence of triethylamine; anhydrosilychristin was prepared from silychristin by reflux in $\mathrm{HCl} / \mathrm{EtOH}$ and isosilychristin was isolated from silymarin by chromatography on an ASAHIPAK GS-310 20f column (Showa Denko K. K., Tokyo, JP). The NMR and MS spectra of compounds used were identical to the authentic standards available in the Laboratory of Biotransformation, Institute of Microbiology, CAS, Prague [1].

\subsection{Antioxidant Capacity}

An oxygen radical absorption capacity (ORAC) assay was performed according to [20]. Briefly, a stock solution of fluorescein $(0.44 \mathrm{mg} / \mathrm{mL})$ was prepared in phosphate-buffered saline (PBS, $\mathrm{pH} 7.4$ ) and stored in a freezer $\left(-20^{\circ} \mathrm{C}\right)$ wrapped in aluminum foil. Prior to use, $167 \mu \mathrm{L}$ of the stock solution was diluted with $25 \mathrm{~mL}$ of PBS. Using a dispenser (MultiFlo Microplate Dispenser, BioTek Instruments, Winooski, VT, USA), $50 \mu \mathrm{L}$ of this solution was split into the wells of a 96-well plate. The concentration range $(1.25-20 \mu \mathrm{M})$ of the samples was prepared by the binary dilution of the samples. Two microliters of the samples and $23 \mu \mathrm{L}$ of PBS were added to the wells. After 15 min of incubation $\left(37^{\circ} \mathrm{C}\right), 25 \mu \mathrm{L}$ of freshly prepared AAPH $(60 \mathrm{mg} / \mathrm{mL})$ was added to each well except for the negative control, where AAPH was replaced with PBS. Immediately after the addition, the fluorescence (ex./em., 485/535 nm) 
was recorded for $2 \mathrm{~h}$ with a measurement step of 5 min using a microplate reader (SpectraMax i3 Multi-Mode Detection Platform, Molecular Devices, San Jose, CA, USA).

For the cellular antioxidant activity (CAA) assay, the HepG2 cell line (ATCC, CCL-23TM, Manassas, VA, USA) was cultivated in EMEM supplemented with $10 \%$ of FBS, $2 \mathrm{mM}$ L-glutamine and $1 \times$ Antibiotic Antimycotic Solution. The cells were cultivated in a $\mathrm{CO}_{2}$ incubator $\left(5 \% \mathrm{CO}_{2}, 37^{\circ} \mathrm{C}\right.$, Thermo Fisher Scientific) and passaged twice per week according to a standardized protocol using a trypsin-EDTA solution. For the experiments, $100 \mu \mathrm{L}$ of the cells with density corresponding to $1 \times 10^{6}$ cells $/ \mathrm{mL}$ (Cellometer Auto T4 Bright Field Cell Counter, Nexcelom Bioscience, Lawrence, MA, USA) were split into 96-well plates. After $24 \mathrm{~h}$, the cells were washed 3× with PBS (MultiFlo Multi-Mode Dispenser, BioTek) and DMEM supplemented with the DCFH-DA $(0.0125 \mathrm{mg} / \mathrm{mL})$ was added to each well together with the tested samples in the concentration range 0.5-2.25 $\mu \mathrm{M}$. After $1 \mathrm{~h}$ incubation in a $\mathrm{CO}_{2}$ incubator, the medium was manually replaced with AAPH solution $(0.16 \mathrm{mg} / \mathrm{mL}$ in PBS) and the fluorescence was immediately recorded (ex./em. $485 / 540 \mathrm{~nm}$ ) for $2 \mathrm{~h}$ in 5-min steps. This protocol was slightly modified version of a published procedure [21].

\subsection{Anti-Inflammatory Properties}

Macrophages (RAW 264.7, Sigma-Aldrich) were cultivated in DMEM supplemented with 2 mM L-glutamine and $1 \times$ antibiotic antimycotic solution, similarly to the HepG2 cells. However, this cell line was not detached by the trypsin-EDTA solution, but mechanically with a scraper. For the experiment, the cells were seeded at $1 \times 10^{6}$ cells/mL into the 96 -well plates. After $48 \mathrm{~h}$, the cells were washed $3 \times$ with PBS, LPS $(1 \mu \mathrm{g} / \mathrm{mL}$ in MEM) and the samples in the concentration range of $6.25-100 \mu \mathrm{M}$ were added to a final volume of $100 \mu \mathrm{L}$. After $24 \mathrm{~h}$, the medium was mixed with Griess reagent $(0.04$ $\mathrm{g} / \mathrm{mL}$, prepared freshly in deionized water, Sigma-Aldrich) in a 1:1 ratio in a new 96-well plate. The absorbance was measured at $540 \mathrm{~nm}$ after $15 \mathrm{~min}$. The cells were incubated with resazurin $(0.03 \mathrm{mg} / \mathrm{mL}$ in PBS) for $2 \mathrm{~h}$, after which the fluorescence was recorded (ex./em. 560/590 nm).

\subsection{Inhibition of P-Glycoprotein}

The in vitro inhibition of P-gp was tested using the Pgp-Glo Assay System according to the manufacturer's instructions. Briefly, the reaction mixture contained Pgp-Glo Assay buffer (control), ATP standards (for the construction of the calibration curve), $\mathrm{Na}_{3} \mathrm{VO}_{4}$ (P-gp inhibitor), verapamil (P-gp substrate, positive control), P-gp containing membranes, and MgATP in a total volume of $50 \mu \mathrm{L}$. Samples $(2.5 \mu \mathrm{L}$; in the concentration range $0.7-0 \mathrm{mM})$ were added and the reaction was incubated for $1 \mathrm{~h}$ in $37^{\circ} \mathrm{C}$. The reaction was stopped by the addition of the detection reagent $(50 \mu \mathrm{L})$. After 20 min of incubation, the luminescence was read.

The basal luminescence (basal $\triangle R L U$ basal) was expressed as the difference between the relative luminescence of $\mathrm{Na}_{3} \mathrm{VO}_{4}$ and that of the control. The luminescence $(\triangle \mathrm{RLU})$ of the samples was calculated as the difference between the relative luminescence of $\mathrm{Na}_{3} \mathrm{VO}_{4}$ and that of the samples. For the P-gp inhibitors, the specific activity of P-gp was determined using the standard ATP curve and calculating the amount of nanomoles of ATP consumed per $\mu$ g of P-gp per minute. The standard ATP curve was determined by linear regression and the concentrations of ATP consumed in the samples were recalculated by the subsequent standard interpolation of RLU ATP.

\subsection{Sensitization of MDR Cell Line}

A sub-line of a human ovarian carcinoma cell line resistant to doxorubicin (HOC/ADR, A2780/ADR) was purchased from Sigma-Aldrich together with its non-resistant parental line (HOC, A2780). Both cell lines were cultivated in DMEM supplemented with $10 \%$ FBS and $1 \times$ antibiotic antimycotic solution. In addition, the cultivation medium for HOC/ADR cells was supplemented with $0.1 \mu \mathrm{M}$ doxorubicin. The cells were cultivated and sub-cultured as described above for the HepG2 cell line. For the experiment, the cells were seeded at a concentration of $1 \times 10^{5}$ cells/mL into the wells of 96-well plates. After $24 \mathrm{~h}$, the cells were washed $3 \times$ with PBS and fresh DMEM supplemented with the flavonolignan 
samples $(0,10,20$ or $30 \mu \mathrm{M})$ was added to both cell lines. The concentration range of doxorubicin $(0.3-80 \mu \mathrm{M})$ was then applied. After $72 \mathrm{~h}$, the viability of the cells was evaluated by resazurin assay as described in Section 2.3. The fold change [22] was calculated as the ratio of $\mathrm{IC}_{50}$ for doxorubicin and $\mathrm{IC}_{50}$ for the doxorubicin co-treated with the tested sample. A fold change higher than 1 indicates a synergistic effect, while a fold change lower than 1 means an antagonistic effect.

\subsection{Inhibition of Expression of Transporters Responsible for MDR Phenotype}

For the transporter expression profiling, both cell lines-HOC and HOC/ADR were seeded into $5 \mathrm{~cm}$ Petri dishes at a concentration corresponding to $1 \times 10^{5}$ cells $/ \mathrm{mL}$. After $24 \mathrm{~h}$, the cells were washed with PBS and fresh DMEM was added. The tested concentration of the samples was $10 \mu \mathrm{M}$. Doxorubicin was applied at a concentration equal to $\mathrm{IC}_{25}$. The cells were cultivated with appropriate samples for $48 \mathrm{~h}$, after which the cells were harvested using the standard procedure and centrifuged $\left(3200 \times g ; 10 \mathrm{~min}, 4^{\circ} \mathrm{C}\right)$. The pellets were washed twice with PBS: (i) $2 \mathrm{~mL}$ of pre-cooled PBS $(5400 \times g$; $\left.10 \mathrm{~min}, 4^{\circ} \mathrm{C}\right)$; and (ii) $1 \mathrm{~mL}$ of pre-cooled PBS $\left(10,000 \times \mathrm{g} ; 3 \mathrm{~min}, 4^{\circ} \mathrm{C}\right)$. The pellet was resuspended in $1 \mathrm{~mL}$ of Trizol (Invitrogen, Carlsbad, CA, USA) and stored at $-80^{\circ} \mathrm{C}$.

The RNA concentration was determined with a Quan-iT RiboGreen RNA Assay Kit (Invitrogen) using the Infinite M200 plate reader (Tecan, Männedorf, Switzerland). The cDNA synthesis was performed from $0.5 \mu \mathrm{g}$ of total RNA with a RevertAid First Strand Synthesis cDNA Kit (MBI Fermentas, Vilnius, Lithuania). The quality of cDNA was verified by amplifying the ubiquitin C gene fragment [23].

Quantitative real-time PCR (qPCR) was performed using the ViiA7 Real-Time PCR System (Life Technologies, Camarillo, CA, USA) with a 384-well block. The reaction mixture consisted of $0.25 \mu \mathrm{L}$ of specific 20× TaqMan Gene Expression Assay (Life Technologies); assays used in the study are listed in Table A1), $1 \mu \mathrm{L}$ of $5 \times$ HotFIREPol Probe qPCR Mix Plus (Solis Biodyne, Tartu, Estonia), $1.75 \mu \mathrm{L}$ of RNase free water and $2 \mu \mathrm{L}$ of $8 \times$ diluted cDNA. The final reaction volume was $5 \mu \mathrm{L}$. Cycling parameters were: initial hold at $50{ }^{\circ} \mathrm{C}$ for $2 \mathrm{~min}$, initial denaturation at $95^{\circ} \mathrm{C}$ for $10 \mathrm{~min}$, followed by 40 cycles of $95^{\circ} \mathrm{C}$ for $15 \mathrm{~s}$ and $60^{\circ} \mathrm{C}$ for $1 \mathrm{~min}$. Fluorescence values were acquired after each extension phase. Samples were analyzed in duplicates, and samples with a standard deviation of duplicates $>0.5 \mathrm{Ct}$ were re-analyzed. A non-template control containing nuclease-free water instead of cDNA was used. The real-time PCR study followed the MIQE guidelines [24]. Relative transcript levels of the estimated genes in the cell lines were compared using the software REST 2009 (Qiagen, Hilden, Germany).

\subsection{Data Processing and Statistical Analysis}

The experiments were done with the appropriate number $(n)$ of repetitions, which are stated in respective figure captions. The relative activity (Figures 2-4) was evaluated as a percentage according to the formula:

$$
R A(\%)=100 \frac{\text { slope of sample fluorescence - average slope of } \mathrm{NC}}{\text { average slope of } \mathrm{PC}-\text { average slope of } \mathrm{NC}} .
$$

$\mathrm{IC}_{50}$ values (Tables 1 and 2) were determined using the software GraphPad Prism 7 (GraphPad Software, San Diego, CA, USA) — non linear regression:

$$
\mathrm{Y}=\frac{\text { Bottom }+(\text { Top }- \text { Bottom })}{1+10((\operatorname{LogIC}-\mathrm{X}) * \text { HillSlope })}
$$

The data are presented as the averages of the repetitions with the standard error of the mean (SEM). Statistical significance was checked with the Excel $t$-test function (two-tailed distribution, heteroscedastic type). One-way analysis of variance (ANOVA) was used, followed by Duncan's post hoc test $(P<0.05)$, to show the differences between the groups. For ANOVA, Statistica software (Tibco Software Inc., Tulsa, OK, USA), version 12, was used. 


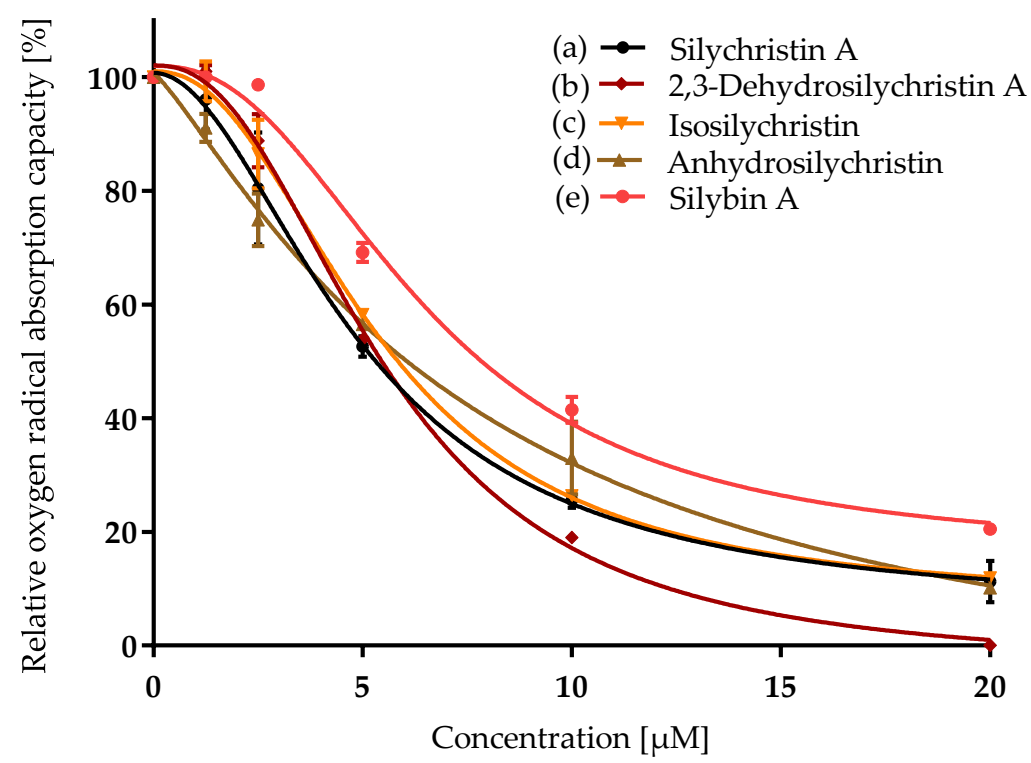

Figure 2. Relative oxygen radical absorption capacity (ORAC) of silychristin derivatives: (a) silychristin A; (b) 2,3-dehydrosilychristin A; (c) isosilychristin; (d) anhydrosilychristin; (e) silybin A. Data are presented as the average of two measurements with the respective standard error of the mean. The Ymax /Ymin values were as follows: (a) 100/11 \pm 2; (b) $101 \pm 1 / 0$; (c) 100/12 \pm 0.1 ; (d) 100/10 \pm 0.1 ; (e) $100 / 20 \pm 0.8$.

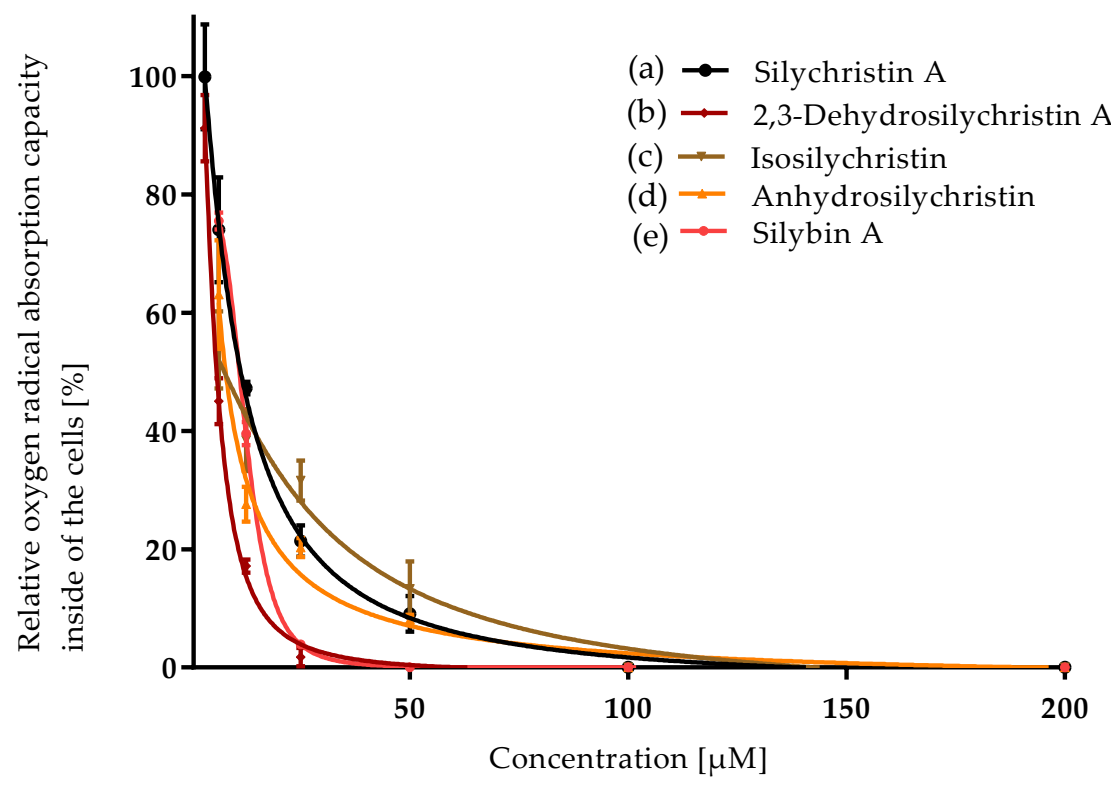

Figure 3. Relative oxygen radical absorption capacity of silychristin derivatives in cellular antioxidant activity assay (CAA, HepG2 cells): (a) silychristin A; (b) 2,3-dehydrosilychristin A; (c) isosilychristin; (d) anhydrosilychristin; (e) silybin A. Data are presented as the average of three measurements with respective standard error of the mean. The $Y \max / Y \min$ values were as follows: (a) $100 \pm 5 / 0$; (b) $91 \pm 3 / 0$; (c) $54 \pm 4 / 0$; (d) $63 \pm 5 / 0$; (e) $76 \pm 1 / 0$. 


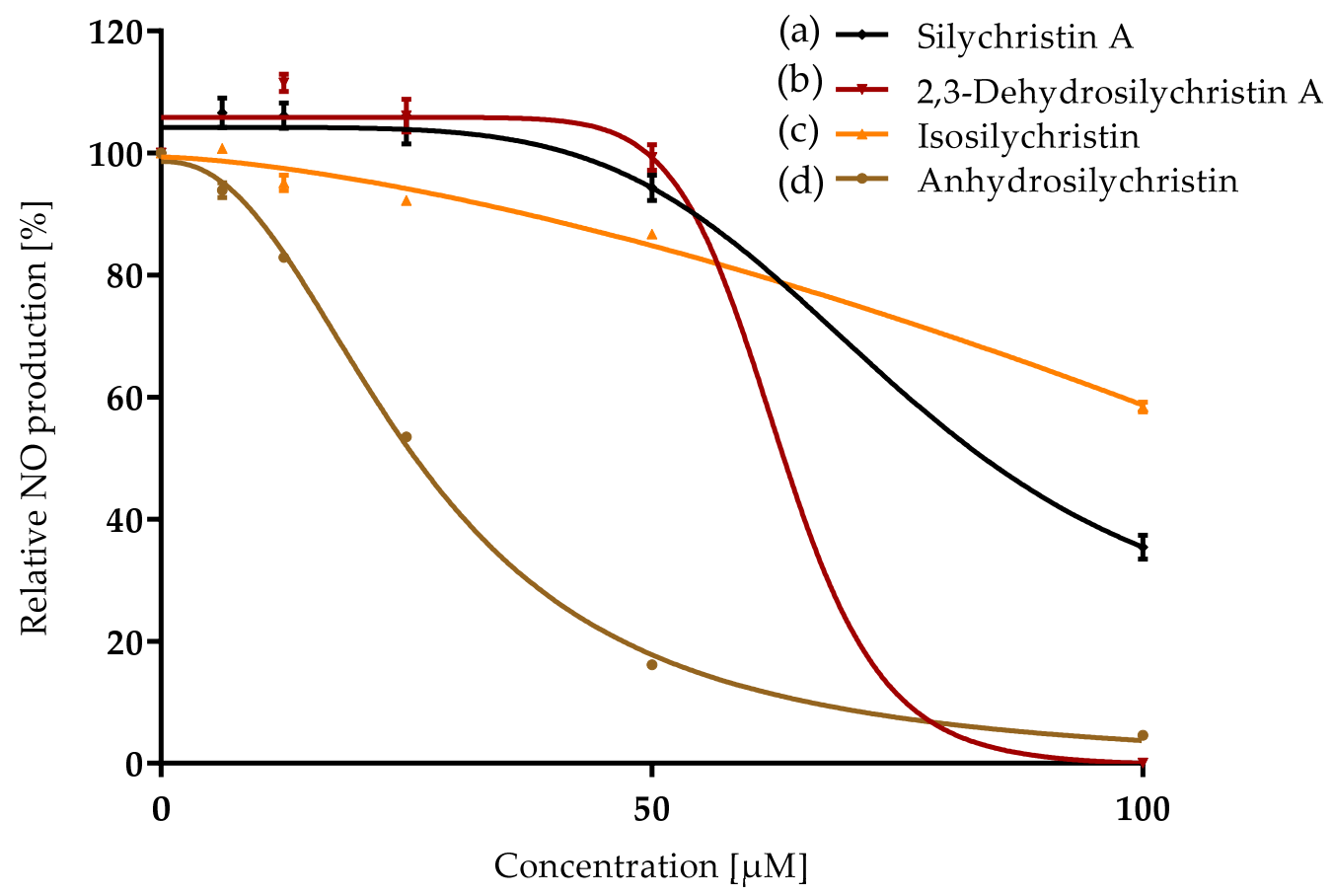

Figure 4. Relative nitrite oxide production as the first marker of inflammation affected by silychristin derivatives: (a) silychristin A; (b) 2,3-dehydrosilychristin A; (c) isosilychristin; (d) anhydrosilychristin. Data are presented as the average of three measurements with respective standard error of the mean. The Ymax /Ymin values were as follows: (a) $107 \pm 2 / 35 \pm 2$; (b) $112 \pm 1 / 0$; (c) 100/58 \pm 1 ; (d) 100/5 \pm 0.4.

Table 1. Concentration $[\mu \mathrm{M}]$ that halved the antioxidant, anti-inflammatory and efflux pump modulating activity $\left(\mathrm{IC}_{50}\right)$ of silychristin and its derivatives.

\begin{tabular}{ccccc}
\hline Compound & ORAC & CAA & NO Production & P-gp \\
& IC $_{\mathbf{5 0}}[\boldsymbol{M M}]$ & IC $_{\mathbf{5 0}}[\boldsymbol{M M}]$ & IC $_{\mathbf{5 0}}[\boldsymbol{\mu M}]$ & IC $_{\mathbf{5 0}}[\boldsymbol{\mu M}]$ \\
\hline Silychristin A & $5.4 \pm 0.2^{\mathrm{a}}$ & $11.4 \pm 0.5^{\mathrm{b}, \mathrm{c}}$ & $65 \pm 3^{\mathrm{d}}$ & $21 \pm 1^{\mathrm{b}}$ \\
2,3-Dehydrosilychristin A & $5.4 \pm 0.1^{\mathrm{a}}$ & $6.0 \pm 0.2^{\mathrm{a}}$ & $36.0 \pm 0.2^{\mathrm{b}}$ & $15.6 \pm 0.5^{\mathrm{a}}$ \\
Isosilychristin & $6.0 \pm 0.1^{\mathrm{a}}$ & $13 \pm 2^{\mathrm{c}}$ & $59.8^{\mathrm{a}} \pm 0.8^{\mathrm{c}}$ & $25.9^{\mathrm{a}} \pm 0.4^{\mathrm{c}}$ \\
Anhydrosilychristin & $5.77 \pm 0.05^{\mathrm{a}}$ & $8.0 \pm 0.7^{\mathrm{a}} \mathrm{b}$ & $22.5 \pm 0.3^{\mathrm{b}}$ & $16.8 \pm 0.2^{\mathrm{a}}$ \\
\hline
\end{tabular}

ORAC-oxygen radical absorption capacity; CAA-cellular antioxidant activity assay; NO production - anti-inflammatory activity; P-gp-inhibition of P-glycoprotein (transmembrane efflux pump). Data are presented as the concentration $(\mu \mathrm{M})$ that halved the respective activity $\left(\mathrm{IC}_{50}\right)$; average of three (in the case of ORAC, only two) repetitions \pm standard error of the mean. Letters indicate the differences between the groups (ANOVA followed by Duncan's post hoc test, $P<0.05$ ) within one assay; the different assays were evaluated independently on each other. Statistically significant levels were denoted by different letters.

Table 2. Sensitization of doxorubicin-resistant human ovarian adenocarcinoma cell line by silychristin A and its derivatives expressed as IC50.

\begin{tabular}{ccc}
\hline IC $_{\mathbf{5 0}}[\boldsymbol{\mu M}]$ & HOC & HOC/ADR \\
\hline Silychristin A & $144 \pm 2$ & $184 \pm 5$ \\
2,3-Dehydrosilychristin A & $50.8 \pm 0.9$ & $68 \pm 9$ \\
Isosilychristin & $209 \pm 3$ & $115 \pm 4$ \\
Anhydrosilychristin & $45 \pm 4$ & $66 \pm 3$ \\
Doxorubicin & $0.022 \pm 0.001$ & $6.2 \pm 0.3$ \\
\hline
\end{tabular}

Data are expressed as the concentration $(\mu \mathrm{M})$ that halved the growth of the population $\left(\mathrm{IC}_{50}\right)$ of the sensitive human ovarian adenocarcinoma cell (HOC) and doxorubicin-resistant HOC/ADR cell lines. 


\section{Results}

\subsection{Antioxidant Capacity}

Silychristin A and its derivatives were compared for their antioxidant capacity by the classical chemical method (ORAC) and by measurement of their radical scavenging activity inside the cells (CAA). All the samples exhibited concentration-dependent antioxidant properties in both assays (Figures 2 and 3, Table 1).

In the ORAC assay, silychristin A exhibited a similar oxygen radical capacity to its derivatives, with no statistically significant differences among the respective compounds (Table 1). The antioxidant potential of silychristin A and its derivatives was compared to that of silybin (the diastereomer A was used) previously assumed to be the strongest antioxidant component of the silymarin complex. Although the $\mathrm{IC}_{50}$ value of silybin $\mathrm{A}$ was higher $(6.5 \pm 0.6)$, the $t$-test evaluated the difference as insignificant. In the cell-based assay, the results were quite different (Figure 3). 2,3-Dehydrosilychristin $A$ and anhydrosilychristin were found to be the best antioxidant compounds followed by silychristin A, silybin A and isosilychristin. The $p$-value of the $t$-test evaluating the difference between silychristin A and 2,3-dehydrosilychristin A was 0.006, the $p$-value of the difference between silychristin A and anhydrosilychristin was 0.02 . Therefore, both 2,3-dehydro- and anhydrosilychristin exhibited better antioxidant activity within the cells than silychristin A. In addition, both derivatives were stronger antioxidants than silybin A, with the $p$-value being 0.002 for 2,3-dehydro and 0.05 for the anhydro derivative (Table 1).

\subsection{Anti-Inflammatory Properties}

Inflammation was stimulated in RAW 264.7 macrophages by the addition of bacterial lipopolysaccharides. As the first signal molecule, nitrite oxide was produced by cells and detected in the assay used. Silychristin A as well as its derivatives were able to inhibit nitrite oxide production in a concentration-dependent manner (Figure 4) when added to the cultivation medium together with the lipopolysaccharide. Anhydrosilychristin was evaluated as the strongest anti-inflammatory agent followed by 2,3-dehydrosilychristin A (Table 1). Almost double concentrations of isosilychristin and silychristin A were required to achieve the same effect. The $p$-values of the $t$-test evaluating the difference between silychristin A and its derivatives (isosilychristin, 2,3-dehydrosilychristin A and anhydrosilychristin) were $0.2 ; 0.007$ and 0.003 , respectively. Thus, both 2,3-dehydro- and anhydro derivatives exhibited better anti-inflammatory activity than the parent compound.

\subsection{Inhibition of P-Glycoprotein}

For the evaluation of the ability of silychristin A and its derivatives to inhibit P-gp in vitro, the isolated fractions of the membranes containing this transmembrane protein were used. This assay is based on the quantification of ATP consumed by active P-gp since inhibited P-gp does not change the ATP level. For P-gp stimulators, the $\triangle$ RLU of samples is higher than the basal $\Delta$ RLU. If the $\triangle R L U$ of the samples is equal to the basal $\Delta R L U$, the samples have no effect on P-gp. In contrast, P-gp inhibitors exhibited a $\triangle R L U$ that was lower than the basal $\triangle R L U$. Both silychristin $A$ and its derivatives inhibited P-gp in a concentration-dependent manner (Figure 5). 2,3-Dehydrosilychristin A and anhydrosilychristin exhibited the lowest $\mathrm{IC}_{50}$ values (Table 1). Isosilychristin was a slightly weaker inhibitor than silychristin A. The $p$-value of the $t$-test comparing the difference between silychristin A and its derivatives 2,3-dehydrosilychristin A, anhydrosilychristin, and isosilychristin were 0.05, 0.1 and 0.05, respectively. Moreover, both silychristin A and 2,3-dehydrosilychristin A limited ATP consumption to only $40 \%$ of the negative control, even at the highest concentrations (100-500 $\mu \mathrm{M})$, in contrast to anhydrosilychristin and isosilychristin, which lowered the consumption of ATP to 0 at relatively low concentrations (75 and $225 \mu \mathrm{M}$, respectively; Figure 5). 


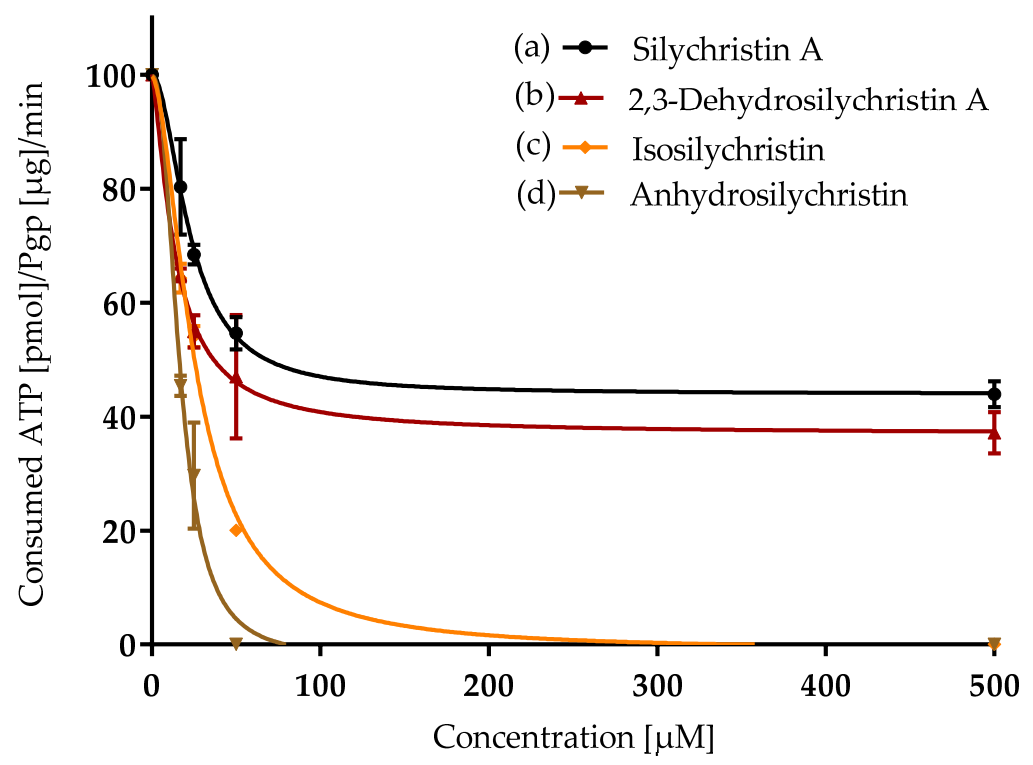

Figure 5. Inhibition of P-glycoprotein (transmembrane efflux pump belonging to the ATP binding cassette family) by silychristin derivatives: (a) silychristin A; (b) 2,3-dehydrosilychristin A; (c) isosilychristin; (d) anhydrosilychristin. Data are presented as the average of three measurements with corresponding standard error of the mean. The $Y_{\max } / Y_{\min }$ values were as follows: (a) 100/44 \pm 2; (b) $100 / 37 \pm 2$; (c) $100 / 0$; (d) $100 / 0$.

\subsection{Sensitization of the Multidrug-Resistant Cell Line}

In the previous section, the ability of silychristin A and its derivatives to inhibit the P-gp pump in vitro was demonstrated. Therefore, the human ovarian adenocarcinoma cell line resistant to doxorubicin was the obvious follow-up to the study under real conditions. The commercial doxorubicin-sensitive (HOC) and doxorubicin-resistant (HOC/ADR) cell lines were characterized for their sensitivity to silychristin A, its derivatives and doxorubicin. The HOC/ADR cell line was several times (approximately $300 \times$ ) more resistant to doxorubicin than its parental HOC cell line (Table 2). As predicted, for both cell lines silychristin A and its derivatives were only toxic at high concentrations $(>50 \mu \mathrm{M})$. The sensitive cell line was slightly more sensitive than the resistant cell line.

The sensitization of the resistant cell line was achieved by the addition of a single dose of silychristin A or its derivatives into the cultivation medium. After that, a concentration range of doxorubicin was applied in order to determine the $\mathrm{IC}_{50}$ of doxorubicin. Finally, the sensitization rate was determined as the ratio of the $\mathrm{IC}_{50}$ of doxorubicin to the $\mathrm{IC}_{50}$ of doxorubicin affected by the presence of silychristin A or its derivatives. At the lowest concentration point $(10 \mu \mathrm{M})$, isosilychristin did not influence the HOC/ADR cell line; a mild effect was observed for the 2,3-dehydro- and anhydro derivative, and the highest sensitization was detected with silychristin $\mathrm{A}$. When the concentration of silychristin A and its derivatives was doubled $(20 \mu \mathrm{M})$, the sensitization of the HOC/ADR cell line was almost $4 \times$ more important (Table 3 ). Both isosilychristin and anhydrosilychristin affected the resistant cell line only slightly or not at all. 
Table 3. Doxorubicin-sensitization rate of doxorubicin-resistant human ovarian carcinoma cells (HOC/ADR) co-cultivated with the presence of silychristin derivatives.

\begin{tabular}{ccc}
\hline Compound & $\mathbf{1 0} \boldsymbol{\mu} \mathbf{M}$ & $\mathbf{2 0} \boldsymbol{\mu M}$ \\
\hline Silychristin A & $(1.7 \pm 0.2) \times$ & $(4.0 \pm 0.2) \times$ \\
2,3-Dehydrosilychristin A & $(1.3 \pm 0.1) \times$ & $(4.8 \pm 0.3) \times$ \\
Isosilychristin & $(1.0 \pm 0.1) \times$ & $(1.5 \pm 0.1) \times$ \\
Anhydrosilychristin & $(1.5 \pm 0.1) \times$ & $(1.0 \pm 0.0) \times$ \\
\hline
\end{tabular}

The sensitization rate was determined as the ratio of doxorubicin $\mathrm{IC}_{50}$ and doxorubicin + derivatives $\mathrm{IC}_{50}$.

\subsection{Inhibition of $A B C$ Transporters Expression}

Based on the finding that silychristin A and its derivatives are able to sensitize the HOC/ADR cell line, we addressed the question whether the sensitization is only caused by P-gp inhibition or by the downregulation of the corresponding gene expression. To clarify this issue, both cell lines were analyzed for the expression profiles of their $\mathrm{ABC}$ superfamily genes. The comparison of the RNA expression profiles of the sensitive and resistant cell lines is given in Appendix A Table A1. A low or undetectable level of expression was characteristic for 11 out of $42 \mathrm{ABC}$ transporters genes ( $A B C A 4, A B C A 6, A B C A 8, A B C A 9, A B C A 10, A B C A 12, A B C A 13, A B C B 4, A B C B 11, A B C C 3, A B C C 9$, $A B C G 8)$. The main difference between the two cell lines was the high expression of the $A B C B 1$ gene (P-gp) in the resistant cell line, and no expression of this gene in the sensitive cell line. Moreover, the resistant cell line expressed a significantly higher amount of the $A B C C 2$ gene (BCRP protein). This overexpression was up to $400 \times$ when comparing the resistant and sensitive cell lines. In addition, there was a statistically significant overexpression of 20 other $\mathrm{ABC}$ genes in the resistant cell line.

After the treatment of the HOC/ADR cell line with both silychristin A and its derivatives at 10 $\mu \mathrm{M}$, the expression profile of the $A B C$ superfamily genes was affected considerably (Appendix $A$, Table A2). In each case, the $A B C A 2$ and $A B C F 1$ genes were downregulated by $25 \%$ (silychristin A and 2,3-dehydrosilychristin A)—32\% (anhydrosilychristin) and 79\% (anhydrosilychristin) - 89\% (isosilychristin), respectively. On the other hand, both the $A B C D 1$ and $A B C F 2$ genes were upregulated by each of the tested compounds by 55\% (anhydrosilychristin) - $78 \%$ (silychristin A) and 67\% (anhydrosilychristin)-105\% (silychristin A), respectively. The most significant expression profile changes were caused by anhydrosilychristin (altering the expression of $21 \mathrm{ABC}$ genes) followed by 2,3-dehydrosilychristin A (altering the expression of 18 ABC genes). In contrast, both silychristin A and isosilychristin treatment only affected the expression of nine $A B C$ genes. As described above, doxorubicin resistance is mainly caused by the over-expression of P-gp ( $A B C B 1$ gene) and BCRP ( $A B C C 2$ gene) in the HOC/ADR cell line. Therefore, we focused on the changes in the expression of these two genes, which were substantially affected by anhydrosilychristin. The $A B C B 1$ and $A B C C 2$ gene expression decreased by $28 \%$ and $40 \%$ respectively after the treatment with anhydrosilychristin. Isosilychristin was only able to downregulate the expression of the $A B C B 1$ gene by $20 \%$. Neither silychristin A nor 2,3-dehydrosilychristin A changed the expression of the dominant $A B C$ transporters in the HOC/ADR cells.

\section{Discussion}

The antioxidant properties of the silymarin complex and its components have been studied extensively (summarized, e.g., in [25]). The methodology for such testing was mainly based on the application of biochemical assays that have only limited relevance to the in situ conditions in tissues or the whole organism. Therefore in this study we evaluated the antioxidant properties of silychristin A, a neglected but abundant silymarin flavonolignan, and structurally related compounds by two distinct methods. An ORAC assay was performed, which is a classical biochemical method that determines the ability of the tested compounds to serve as quenchers of peroxyl radicals generated from 2,2' -azo-bis(2-amidinopropane) dihydrochloride (AAPH) in order to protect fluorescein against 
oxidation. This assay serves predominantly for the physical description of the tested compounds [26]. To reflect the biological relevance, the cellular antioxidant activity (CAA) was measured using a liver carcinoma cell line. The main difference between CAA and classical biochemical assays is that in CAA the compound must enter the cell to fulfill its role as an antioxidant. The CAA assay partially includes the aspects of both uptake and metabolism [21]. Despite the above-mentioned advantages, CAA does not provide any insight into the destiny of the tested compounds in the whole organism, including their distribution, clearance or, e.g., the ability of the tested compounds to induce the transcription of antioxidant enzymes [27].

The antioxidant activity of silymarin and its components is usually only measured by biochemical assays that demonstrate good antioxidant properties [28]. However, these antioxidant properties have been rarely demonstrated in living cells [29]. Due to difficulties with isolating the components of silymarin, the cellular antioxidant activity was only published for its main components such as silybin (and often as a diastereomeric mixture) [30], 2,3-dehydrosilybin [31], and taxifolin [32] and data on other components are still missing.

One of the recent trends in antioxidant mechanism studies shows that many nutritional antioxidants are not able to scavenge oxygen radicals in vivo. Instead, at their physiological nontoxic concentrations, they maintain nucleophilic tonus by a mechanism called "para-hormesis" leading to the activation of the transcription of the antioxidant enzymes, which leads to protection and activation of repair mechanisms [33]. This type of silymarin action was reported; specifically the ability to prevent DNA damage in human blood cells [34] or to increase the antioxidant enzyme transcription in animals [35].

Here, we report on the ability of silychristin A and its derivatives to scavenge oxygen radicals. As discussed above, each of them is a strong antioxidant, which was demonstrated by our results as well. We observed no difference either between silychristin A and its derivatives or between the derivatives and silybin A. However, quite a different situation was observed in the cellular environment. In the antioxidant activity assay; 2,3-dehydro- and anhydro derivatives were almost twice active as isosilychristin, silychristin A and silybin A. The main explanation probably lies in the differences in their structure, namely the additional double bond at position C-2, C-3 for 2,3-dehydrosilychristin and at position C-10, C-11 in the structure of anhydrosilychristin (Figure 1). This is in line with the previously reported DPPH and ABTS scavenging, reducing and anti-lipoperoxidant activity of not only 2,3-dehydrosilychristin and anhydrosilychristin, but also other 2,3-dehydroflavonolignans compared with their parent flavonolignans [1,4,36-38].

The anti-inflammatory activity of silymarin has been previously reported $[39,40]$, showing its ability to affect inflammation via the suppression of the NF- $\kappa$ B signaling pathway and TNF- $\alpha$ activation. Moreover, its ability to downregulate COX-2, LOX, inducible iNOS and IL-1 was demonstrated as well [41]. However, many researchers have never taken into account the fact that silymarin is a complex mixture of several flavonolignans and flavonoids [42] and data on the anti-inflammatory activity of pure compounds are mostly [43] still missing. Here, we demonstrate that silychristin A is able to decrease an inflammatory marker (NO) in a concentration-dependent manner and its anhydro- and iso- derivatives possess almost double anti-inflammatory activity.

In general, anticancer activity is among other things connected to the ability to inhibit oncologically important transmembrane transporters. Thyroid hormone transmembrane transporter (THTT) is one such transporter, whose inhibition can reduce the aggressiveness or delay the onset of cancer [44]. Based on a THTT inhibition study with silymarin components, silychristin was evaluated as the most effective inhibitor, with an $\mathrm{IC}_{50}$ in the $\mathrm{nM}$ range $[45,46]$. On the other hand, the $\mathrm{Na}^{+} / \mathrm{K}^{+}$ATPase inhibitors usually used in the treatment of cardiovascular diseases have recently demonstrated a beneficial effect on several cancers' tissues [47]. The first anticancer drugs based on $\mathrm{Na}^{+} / \mathrm{K}^{+} \mathrm{ATPase}$ inhibitors are in clinical trials, making this transmembrane pump an emerging target for anticancer therapy [47]. Silychristin was shown to inhibit this pump with an $\mathrm{IC}_{50}$ of ca. $40 \mu \mathrm{M}$ [48]. Since the ability of silychristin to inhibit several transmembrane pumps described as cancer treatment targets has been demonstrated, the modulation of P-glycoprotein activity is another issue that should be resolved. 
P-glycoprotein (P-gp) is a transmembrane efflux pump belonging to the ATP Binding Cassette (ABC) family of transporters. Its physiological function is connected to the export of cytokines, steroid hormones, ions and xenobiotics, which includes anticancer drugs [49]. The inhibition of P-gp has therapeutic importance in sensitizing multidrug-resistant (MDR) tumors to the available commercial drugs. The ability of some flavonolignans to modulate MDR was recently summarized in a comprehensive review [49]. Among them, the silymarin complex has been recognized as an inhibitor of this transmembrane pump $[41,50,51]$ able to reverse the multidrug resistance phenotype in a doxorubicin-resistant breast cancer cell line [52]. Furthermore, silybin, as the main component of the silymarin complex, inhibited P-gp in a concentration-dependent manner [53] and reversed multidrug resistance in a small cell lung carcinoma [54]. However, to the best of our knowledge, other components of the silymarin complex have never been tested for their ability to reverse a multidrug resistance phenotype.

Two main mechanisms could be involved in P-gp activity modulation: direct inhibition of the transporter and/or inhibition of its expression. Based on our results, silychristin $\mathrm{A}$ and 2,3-dehydrosilychristin A modulate P-gp activity mainly via the first means. These compounds exhibited a concentration-dependent ability to decrease both the function of P-gp and decrease the resistance of P-gp overexpressing cells. In addition; neither silychristin A nor 2,3-dehydrosilychristin A affected P-gp expression. 2,3-Dehydrosilychristin A was a slightly better P-gp modulator, probably due to its highly conjugated aromatic structure $[4,36]$; the results were similar for the CAA assay. In contrast, anhydro- and iso- derivatives of silychristin A act as modulators of both P-gp function and P-gp expression. Both compounds decreased P-gp function in a concentration-dependent manner, sensitized the P-gp overexpressing cell line and concurrently affected the P-gp expression. The first report on the modulation of $A B C$ transporter expression profiles by silymarin [55] suggested the upregulation of the $A B C G 5, A B C G 8$ and $A B C A 1$ genes. We attempted to compare these data with our results. However, the first two genes were not expressed in a HOC/ADR cell line, and the last gene was unaffected or slightly downregulated (only by 2,3-dehydrosilychristin A).

\section{Conclusions}

Multidrug resistance (MDR) is one of the major upcoming challenges of the 21st century. One of the main mechanisms of MDR is the overexpression of ABC transporters such as P-glycoprotein (Pgp). Here, we demonstrated that silychristin $\mathrm{A}$ and its derivatives have a broader spectrum of biological activities than has been previously thought. Besides their strong antioxidant and anti-inflammatory activity, both silychristin A and its derivatives are able to inhibit P-gp in a concentration-dependent manner and thus sensitize this multidrug-resistant cancer cell line. The mode of action of silychristin A and 2,3-dehydrosilychristin A could be direct inhibition of the transporter in contrast to iso- and anhydrosilychristin, which modulate the MDR phenotype by inhibiting P-gp expression.

Author Contributions: Conceptualization, J.V. and V.K.; methodology, J.V. and K.V.; software, K.Һ̌.; validation, S.D., K.Š. and R.V.; formal analysis, T.R., J.V.; investigation, S.D., D.B., K.K.; resources, V.K. K.K., J.V. and D.B; data

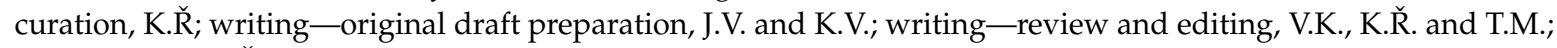
visualization, K. ̌̌.; supervision, V.K, T.M.; project administration, K.V.; funding acquisition, T.R., V.K.

Funding: This work was supported by Czech Science Foundation project 18-00150S, mobility projects from the Czech Ministry of Education, Youth and Sports INTER-COST LTC19007 and LTC19020 (COST Action CA17104 STRATAGEM), by the Operational Program Prague-Competitiveness projects CZ.2.16/3.1.00/21537 and CZ.2.16/3.1.00/24503, and by the Czech National Program of Sustainability NPU I (LO) (MSMT-43760/2015).

Acknowledgments: Lucie Petrásková, Institute of Microbiology, Prague is gratefully acknowledged for determining the purity of the compounds tested. The authors thank Ben Watson-Jones, MEng, for providing language corrections.

Conflicts of Interest: The authors declare no conflict of interest. 
Abbreviations

$\begin{array}{ll}\text { AAPH } & \text { 2,2'-azo-bis-(2-methylpropionamidine) dihydrochloride } \\ \text { ABC } & \text { ATP binding cassette } \\ \text { ADR } & \text { Adriamycin, trade name of doxorubicin } \\ \text { BCRP } & \text { breast cancer resistance protein } \\ \text { BHA } & \text { butylated hydroxyanisole } \\ \text { BHT } & \text { butylhydroxytoluen } \\ \text { CAA } & \text { cellular antioxidant activity } \\ \text { COX-2 } & \text { cyclooxygenase-2 } \\ \text { DCFH-DA } & 2^{\prime}, 7^{\prime} \text {-dichlorofluorescin diacetate } \\ \text { DPPH } & \text { 2,2-diphenyl-1-picrylhydrazyl } \\ \text { DMEM } & \text { Dulbecco's Modified Eagle's Medium - high glucose } \\ \text { EMEM } & \text { Eagle's Minimum Essential Medium } \\ \text { FBS } & \text { fetal bovine serum } \\ \text { FCR } & \text { Folin-Ciocalteu reagent } \\ \text { FRAP } & \text { ferric reducing ability of plasma } \\ \text { HepG2 } & \text { human hepatocellular adenocarcinoma } \\ \text { HOC } & \text { human ovarian adenocarcinoma } \\ \text { HOC/ADR } & \text { human ovarian adenocarcinoma resistant to doxorubicin } \\ \text { IL-1 } & \text { Interleukin-1 } \\ \text { iNOS } & \text { inducible isoform of nitric oxide synthases } \\ \text { LPS } & \text { lipopolysaccharides } \\ \text { LOX } & \text { lipoxygenase } \\ \text { MDR } & \text { multidrug resistance } \\ \text { MEM } & \text { Essential Medium Eagle no phenol red } \\ \text { NF- } \text { B } & \text { nuclear factor kappa-light-chain-enhancer of activated B cells } \\ \text { ORAC } & \text { oxygen radical absorption capacity } \\ \text { P-gp } & \text { P-glycoprotein } \\ \text { PBS } & \text { Phosphate-buffered saline } \\ \text { RAW 264.7 } & \text { mouse macrophages } \\ \text { RLU } & \text { relative luminescence units } \\ \text { THTT } & \text { thyroid hormone transmembrane transporters } \\ \text { TNF- } \alpha & \text { tumor necrosis factor alpha } \\ & \end{array}$




\section{Appendix A}

Table A1. Comparison of ABC (ATP-binding cassette) superfamily genes expression profiles in doxorubicin-sensitive HOC and -resistant HOC/ADR cell lines.

\begin{tabular}{|c|c|c|c|c|c|c|c|}
\hline Gene Symbol & Assay ID & $\begin{array}{c}\text { GenBank } \\
\text { Accession No. }\end{array}$ & Gene Name & Amplicon Length (bp) & $\begin{array}{l}\text { Expression } \\
\text { Difference }\end{array}$ & $P$ & $\begin{array}{l}\text { Resistant versus } \\
\text { Sensitive }\end{array}$ \\
\hline \multicolumn{8}{|l|}{ Reference } \\
\hline PPIA & Hs99999904_m1 & NM_021130.3 & Peptidylprolyl isomerase A & 98 & & & \\
\hline ABCA1 & Hs00194045_m1 & NM_005502.3 & $A B C$, sub-family $A(A B C 1)$, member 1 & 125 & 3.140 & 0.000 & overexpression \\
\hline ABCA2 & Hs00242232_m1 & NM_212533.2 & $A B C$, sub-family $A(A B C 1)$, member 2 & 58 & 1.402 & 0.000 & overexpression \\
\hline ABCA3 & Hs00184543_m1 & NM_001089.2 & $\mathrm{ABC}$, sub-family $\mathrm{A}(\mathrm{ABC} 1)$, member 3 & 77 & 0.487 & 0.161 & \\
\hline ABCA5 & Hs00363322_m1 & NM_172232.2 & $A B C$, sub-family $A(A B C 1)$, member 5 & 100 & 4.595 & 0.000 & overexpression \\
\hline ABCA6 & Hs00365329_m1 & NM_080284.2 & $A B C$, sub-family $A(A B C 1)$, member 6 & 83 & \multicolumn{3}{|c|}{ neither in HOC nor in HOC/ADR } \\
\hline ABCA7 & Hs00185303_m1 & NM_019112.3 & ABC, sub-family A (ABC1), member 7 & 80 & 2.632 & 0.000 & overexpression \\
\hline ABCA8 & Hs00992371_m1 & NM_007168.2 & $A B C$, sub-family $A(A B C 1)$, member 8 & 85 & \multicolumn{3}{|c|}{ neither in HOC nor in HOC/ADR } \\
\hline ABCA9 & Hs00329320_m1 & NM_080283.3 & $A B C$, sub-family $A(A B C 1)$, member 9 & 145 & \multicolumn{3}{|c|}{ neither in HOC nor in HOC/ADR } \\
\hline ABCA10 & Hs00365268_m1 & NM_080282.3 & $A B C$, sub-family $A(A B C 1)$, member 10 & 127 & \multicolumn{3}{|c|}{ neither in HOC nor in HOC/ADR } \\
\hline ABCA12 & Hs00292421_m1 & NR_103740.1 & $\mathrm{ABC}$, sub-family $\mathrm{A}(\mathrm{ABC} 1)$, member 12 & 77 & \multicolumn{3}{|c|}{ neither in HOC nor in HOC/ADR } \\
\hline ABCB1 & Hs00184491_m1 & NM_000927.4 & ABC, sub-family B (MDR/TAP), member 1 & 110 & \multicolumn{3}{|c|}{ no detectable level of expression in $\mathrm{HOC}$} \\
\hline ABCB2 & Hs00388677_m1 & NM_000593.5 & Transporter 1, ABC, sub-family B (MDR/TAP) & 60 & 0.263 & 0.320 & not affected \\
\hline ABCB3 & Hs00241060_m1 & NM_018833.2 & Transporter 2, ABC, sub-family B (MDR/TAP) & 66 & 0.290 & 0.000 & attenuated \\
\hline АВCB4 & Hs00240956_m1 & NM_018850.2 & ABC, sub-family B (MDR/TAP), member 4 & 73 & \multicolumn{3}{|c|}{ neither in HOC nor in HOC/ADR } \\
\hline $\mathrm{ABCB} 6$ & Hs00180568_m1 & NM_005689.2 & ABC, sub-family B (MDR/TAP), member 6 & 60 & 4.339 & 0.000 & overexpression \\
\hline ABCB7 & Hs00188776_m1 & NM_004299.3 & ABC, sub-family B (MDR/TAP), member 7 & 92 & 1.485 & 0.320 & not affected \\
\hline ABCB8 & Hs00185159_m1 & NM_007188.3 & ABC, sub-family B (MDR/TAP), member 8 & 74 & 1.611 & 0.000 & overexpression \\
\hline АВСВ9 & Hs00608640_m1 & NM_203444.2 & ABC, sub-family B (MDR/TAP), member 9 & 75 & 1.185 & 0.000 & overexpression \\
\hline ABCB10 & Hs00429240_m1 & NM_012089.2 & ABC, sub-family B (MDR/TAP), member 10 & 133 & 1.270 & 0.000 & overexpression \\
\hline ABCB11 & Hs00184824_m1 & NM_003742.2 & ABC, sub-family B (MDR/TAP), member 11 & 63 & \multicolumn{3}{|c|}{ neither in HOC nor in HOC/ADR } \\
\hline $\mathrm{ABCC} 1$ & Hs00219905_m1 & NM_004996.3 & ABC, sub-family C (CFTR/MRP), member 1 & 74 & 1.241 & 0.000 & overexpression \\
\hline
\end{tabular}


Table A1. Cont.

\begin{tabular}{|c|c|c|c|c|c|c|c|}
\hline Gene Symbol & Assay ID & $\begin{array}{c}\text { GenBank } \\
\text { Accession No. }\end{array}$ & Gene Name & Amplicon Length (bp) & $\begin{array}{l}\text { Expression } \\
\text { Difference }\end{array}$ & $P$ & $\begin{array}{l}\text { Resistant versus } \\
\text { Sensitive }\end{array}$ \\
\hline \multicolumn{8}{|l|}{ Reference } \\
\hline $\mathrm{ABCC} 2$ & Hs00166123_m1 & NM_000392.3 & $\mathrm{ABC}$, sub-family $\mathrm{C}$ (CFTR/MRP), member 2 & 75 & 399.968 & 0.000 & overexpression \\
\hline $\mathrm{ABCC} 4$ & Hs00195260_m1 & NM_005845.3 & ABC, sub-family C (CFTR/MRP), member 4 & 86 & 1.326 & 0.000 & overexpression \\
\hline ABCC5 & Hs00981089_m1 & NM_005688.2 & $\mathrm{ABC}$, sub-family $\mathrm{C}$ (CFTR/MRP), member 5 & 68 & 1.619 & 0.000 & overexpression \\
\hline ABCC6 & Hs00184566_m1 & NM_001171.5 & ABC, sub-family C (CFTR/MRP), member 6 & 56 & 0.941 & 0.000 & attenuated \\
\hline $\mathrm{ABCC} 10$ & Hs00675716_m1 & NM_033450.2 & $\mathrm{ABC}$, sub-family $\mathrm{C}$ (CFTR/MRP), member 10 & 142 & 2.591 & 0.000 & overexpression \\
\hline $\mathrm{ABCD} 1$ & Hs00163610_m1 & NM_000033.3 & $\mathrm{ABC}$, sub-family D (ALD), member 1 & 101 & 4.417 & 0.000 & overexpression \\
\hline $\mathrm{ABCD} 2$ & Hs00193054_m1 & NM_005164.3 & $\mathrm{ABC}$, sub-family $\mathrm{D}$ (ALD), member 2 & 109 & 0.830 & 0.502 & not affected \\
\hline $\mathrm{ABCD} 3$ & Hs00161065_m1 & NM_002858.3 & ABC, sub-family D (ALD), member 3 & 91 & 1.697 & 0.159 & not affected \\
\hline $\mathrm{ABCD} 4$ & Hs00245534_m1 & NM_005050.3 & ABC, sub-family D (ALD), member 4 & 117 & 0.964 & 0.842 & not affected \\
\hline ABCE1 & Hs01009190_m1 & NM_001040876.1 & $\mathrm{ABC}$, sub-family $\mathrm{E}(\mathrm{OABP})$, member 1 & 91 & 1.207 & 0.000 & overexpression \\
\hline ABCF1 & Hs00153703_m1 & NM_001090.2 & ABC, sub-family F (GCN20), member 1 & 69 & 1.706 & 0.000 & overexpression \\
\hline ABCF3 & Hs00217977_m1 & NM_018358.2 & $\mathrm{ABC}$, sub-family F (GCN20), member 3 & 61 & 1.792 & 0.000 & overexpression \\
\hline ABCG1 & Hs00245154_m1 & NM_207629.1 & ABC, sub-family G (WHITE), member 1 & 58 & 2.532 & 0.000 & overexpression \\
\hline ABCG2 & Hs00184979_m1 & NM_004827.2 & ABC, sub-family G (WHITE), member 2 & 92 & 0.467 & 0.000 & attenuated \\
\hline ABCG4 & Hs00223446_m1 & NM_001142505.1 & ABC, sub-family G (WHITE), member 4 & 93 & 24.936 & 0.000 & overexpression \\
\hline ABCG8 & Hs00223690_m1 & NM_022437.2 & ABC, sub-family G (WHITE), member 8 & 63 & \multicolumn{3}{|c|}{ neither in HOC nor in HOC/ADR } \\
\hline
\end{tabular}


Table A2. Effect of silychristin A and its derivatives $[10 \mu \mathrm{M}]$ on ABC superfamily genes expression profiles in HOC/ADR cell line.

\begin{tabular}{|c|c|c|c|c|c|c|c|c|c|c|c|c|}
\hline \multirow[b]{2}{*}{$\begin{array}{c}\text { Gene } \\
\text { Symbol }\end{array}$} & \multicolumn{3}{|c|}{ Silychristin A } & \multicolumn{3}{|c|}{ 2,3-Dehydrosilychristin A } & \multicolumn{3}{|c|}{ Isosilychristin } & \multicolumn{3}{|c|}{ Anhydrosilychristin } \\
\hline & $\begin{array}{l}\text { Expression } \\
\text { Difference }\end{array}$ & $P$ & $\begin{array}{c}\text { Treated } \\
\text { versus } \\
\text { Untreated }\end{array}$ & $\begin{array}{l}\text { Expression } \\
\text { Difference }\end{array}$ & $P$ & $\begin{array}{l}\text { Treated } \\
\text { versus } \\
\text { Untreated }\end{array}$ & $\begin{array}{l}\text { Expression } \\
\text { Difference }\end{array}$ & $P$ & $\begin{array}{c}\text { Treated } \\
\text { versus } \\
\text { Untreated }\end{array}$ & $\begin{array}{l}\text { Expression } \\
\text { Difference }\end{array}$ & $P$ & $\begin{array}{c}\text { Treated } \\
\text { versus } \\
\text { Untreated }\end{array}$ \\
\hline PPIA & 1.000 & & & 1.000 & & & 1.000 & & & 1.000 & & \\
\hline ABCA1 & 1.217 & 0.321 & & 0.801 & 0.000 & DOWN & 0.856 & 0.665 & & 0.948 & 0.672 & \\
\hline ABCA2 & 0.755 & 0.000 & DOWN & 0.756 & 0.000 & DOWN & 0.743 & 0.000 & DOWN & 0.675 & 0.000 & DOWN \\
\hline ABCA3 & 0.971 & 0.829 & & 0.834 & 0.000 & DOWN & 0.755 & 0.336 & & 0.686 & 0.000 & DOWN \\
\hline ABCA5 & 0.971 & 0.829 & & 0.965 & 0.675 & & 0.864 & 0.499 & & 0.822 & 0.341 & \\
\hline ABCA7 & 1.220 & 0.172 & & 1.241 & 0.000 & UP & 1.142 & 0.166 & & 1.054 & 0.846 & \\
\hline ABCB1 & 0.932 & 0.321 & & 0.863 & 0.654 & & 0.796 & 0.000 & DOWN & 0.722 & 0.000 & DOWN \\
\hline ABCB2 & 0.980 & 0.657 & & 0.825 & 0.347 & & 0.753 & 0.166 & & 0.546 & 0.000 & DOWN \\
\hline ABCB3 & 1.007 & 0.828 & & 0.902 & 0.832 & & 0.962 & 0.669 & & 0.693 & 0.000 & DOWN \\
\hline ABCB6 & 0.799 & 0.000 & DOWN & 0.707 & 0.000 & DOWN & 0.758 & 0.166 & & 0.557 & 0.000 & DOWN \\
\hline ABCB7 & 0.855 & 0.321 & & 0.735 & 0.157 & & 0.769 & 0.166 & & 0.820 & 0.174 & \\
\hline ABCB8 & 0.833 & 0.000 & DOWN & 0.811 & 0.328 & & 0.953 & 0.665 & & 0.554 & 0.000 & DOWN \\
\hline ABCB9 & 0.924 & 0.657 & & 0.743 & 0.000 & DOWN & 0.848 & 0.000 & DOWN & 0.590 & 0.000 & DOWN \\
\hline ABCB10 & 0.883 & 0.657 & & 0.774 & 0.157 & & 0.626 & 0.166 & & 0.568 & 0.000 & DOWN \\
\hline ABCC1 & 0.917 & 0.321 & & 0.774 & 0.000 & DOWN & 0.711 & 0.166 & & 0.654 & 0.000 & DOWN \\
\hline ABCC2 & 1.025 & 0.828 & & 0.869 & 0.675 & & 0.761 & 0.166 & & 0.596 & 0.000 & DOWN \\
\hline ABCC3 & 6.375 & 0.172 & & 5.600 & 0.000 & UP & 4.569 & 0.170 & & 3.812 & 0.174 & \\
\hline ABCC5 & 0.895 & 0.321 & & 0.773 & 0.000 & DOWN & 0.697 & 0.166 & & 0.615 & 0.000 & DOWN \\
\hline ABCC6 & 1.094 & 0.321 & & 0.861 & 0.675 & & 0.841 & 0.499 & & 1.159 & 0.000 & UP \\
\hline ABCC 10 & 1.006 & 0.828 & & 0.752 & 0.000 & DOWN & 0.752 & 0.000 & DOWN & 0.628 & 0.000 & DOWN \\
\hline ABCD1 & 1.775 & 0.000 & UP & 1.664 & 0.000 & UP & 1.700 & 0.000 & UP & 1.552 & 0.000 & UP \\
\hline ABCD2 & 2.925 & 0.000 & UP & 4.374 & 0.000 & UP & 0.827 & 0.497 & & 4.267 & 0.329 & \\
\hline ABCD3 & 0.957 & 0.657 & & 0.793 & 0.504 & & 0.293 & 0.166 & & 0.964 & 0.331 & \\
\hline ABCD4 & 2.146 & 0.172 & & 0.752 & 0.000 & DOWN & 1.822 & 0.000 & UP & 1.686 & 0.174 & \\
\hline ABCE1 & 1.854 & 0.000 & UP & 1.811 & 0.157 & & 2.080 & 0.000 & UP & 2.234 & 0.329 & \\
\hline ABCF1 & 0.161 & 0.000 & DOWN & 0.182 & 0.000 & DOWN & 0.114 & 0.000 & DOWN & 0.208 & 0.000 & DOWN \\
\hline ABCF2 & 2.053 & 0.000 & UP & 2.028 & 0.000 & UP & 1.753 & 0.000 & UP & 1.672 & 0.000 & UP \\
\hline ABCF3 & 1.116 & 0.172 & & 0.464 & 0.000 & DOWN & 0.993 & 0.669 & & 0.799 & 0.000 & DOWN \\
\hline ABCG1 & 1.448 & 0.172 & & 0.844 & 0.000 & DOWN & 0.900 & 0.665 & & 1.760 & 0.000 & UP \\
\hline ABCG2 & 0.891 & 0.657 & & 0.804 & 0.000 & DOWN & 0.922 & 0.830 & & 0.716 & 0.000 & DOWN \\
\hline ABCG4 & 1.854 & 0.000 & UP & 1.533 & 0.000 & UP & 1.513 & 0.166 & & 1.583 & 0.000 & $\mathrm{UP}$ \\
\hline
\end{tabular}




\section{References}

1. Biedermann, D.; Buchta, M.; Holečková, V.; Sedlák, D.; Valentová, K.; Cvačka, J.; Bednářova, L.; Křenková, A.; Kuzma, M.; Skuta, C.; et al. Silychristin: Skeletal alterations and biological activities. J. Nat. Prod. 2016, 79, 3086-3092. [CrossRef] [PubMed]

2. Křenek, K.; Marhol, P.; Peikerová, Ž.; Křen, V.; Biedermann, D. Preparatory separation of the silymarin flavonolignans by Sephadex LH-20 gel. Food Res. Int. 2014, 65, 115-120. [CrossRef]

3. Zanarotti, A. Stereochemistry of silychristin mild dehydrogenation of flavanonols. Heterocycles 1982, 19, 1585-1586. [CrossRef]

4. Pyszková, M.; Biler, M.; Biedermann, D.; Valentová, K.; Kuzma, M.; Vrba, J.; Ulrichová, J.; Sokolová, R.; Mojovic, M.; Popovic-Bijelic, A.; et al. Flavonolignan 2,3-dehydroderivatives: Preparation, antiradical and cytoprotective activity. Free Radic. Biol. Med. 2016, 90, 114-125. [CrossRef] [PubMed]

5. Vostalová, J.; Tinková, E.; Biedermann, D.; Kosina, P.; Ulrichová, J.; Svobodová, A.R. Skin protective activity of silymarin and its flavonolignans. Molecules 2019, 24, 1022. [CrossRef] [PubMed]

6. Egea, J.; Fabregat, I.; Frapart, Y.M.; Ghezzi, P.; Gorlach, A.; Kietzmann, T.; Kubaichuk, K.; Knaus, U.G.; Lopez, M.G.; Olaso-Gonzalez, G.; et al. European contribution to the study of ROS: A summary of the findings and prospects for the future from the COST action BM1203 (EU-ROS). Redox Biol. 2017, 13, $94-162$. [CrossRef] [PubMed]

7. Huyut, Z.; Beydemir, S.; Gulcin, I. Antioxidant and antiradical properties of selected flavonoids and phenolic compounds. Biochem. Res. Int. 2017, 2017, 1-10. [CrossRef]

8. Vrba, J.; Papoušková, B.; Roubalová, L.; Zatloukalová, M.; Biedermann, D.; Křen, V.; Valentová, K.; Ulrichová, J.; Vacek, J. Metabolism of flavonolignans in human hepatocytes. J. Pharm. Biomed. 2018, 152, 94-101. [CrossRef]

9. Valentová, K.; Purchartová, K.; Rýdlová, L.; Roubalová, L.; Biedermann, D.; Petrásková, L.; Křenková, A.; Pelantová, H.; Holečkova-Moravcová, V.; Tesařová, E.; et al. Sulfated metabolites of flavonolignans and 2,3-dehydroflavonolignans: Preparation and properties. Int. J. Mol. Sci. 2018, 19, 2349. [CrossRef]

10. Qin, N.B.; Hu, X.; Li, S.G.; Wang, J.; Li, Z.L.; Li, D.H.; Xu, F.X.; Gao, M.; Hua, H.M. Hypoglycemic effect of silychristin a from Silybum marianum fruit via protecting pancreatic islet cells from oxidative damage and inhibiting $\alpha$-glucosidase activity in vitro and in rats with type 1 diabetes. J. Funct. Food 2017, 38, 168-179. [CrossRef]

11. Hrčková, G.; Kubásková, T.M.; Benada, O.; Kofroňová, O.; Tumová, L.; Biedermann, D. Differential effects of the flavonolignans silybin, silychristin and 2,3-dehydrosilybin on Mesocestoides vogae larvae (cestoda) under hypoxic and aerobic in vitro conditions. Molecules 2018, 23, 2999. [CrossRef] [PubMed]

12. Bijak, M.; Dziedzic, A.; Synowiec, E.; Sliwinski, T.; Saluk-Bijak, J. Flavonolignans inhibit IL1- $\beta$-induced cross-talk between blood platelets and leukocytes. Nutrients 2017, 9, 1022. [CrossRef] [PubMed]

13. Kosina, P.; Paloncyová, M.; Svobodová, A.R.; Zálešák, B.; Biedermann, D.; Ulrichová, J.; Vostalová, J. Dermal delivery of selected polyphenols from Silybum marianum. Theoretical and experimental study. Molecules 2019, 24, 61. [CrossRef] [PubMed]

14. Bijak, M.; Synowiec, E.; Sitarek, P.; Sliwinski, T.; Saluk-Bijak, J. Evaluation of the cytotoxicity and genotoxicity of flavonolignans in different cellular models. Nutrients 2017, 9, 1356. [CrossRef] [PubMed]

15. Tvrdý, V.; Catapano, M.C.; Rawlik, T.; Karlíčková, J.; Biedermann, D.; Křen, V.; Mladěnka, P.; Valentová, K. Interaction of isolated silymarin flavonolignans with iron and copper. J. Inorg. Biochem. 2018, 189, 115-123. [CrossRef] [PubMed]

16. Bijak, M.; Szelenberger, R.; Dziedzic, A.; Saluk-Bijak, J. Inhibitory effect of flavonolignans on the P2Y12 pathway in blood platelets. Molecules 2018, 23, 374. [CrossRef] [PubMed]

17. Bijak, M.; Dziedzic, A.; Saluk-Bijak, J. Flavonolignans reduce the response of blood platelet to collagen. Int. J. Biol. Macromol. 2018, 106, 878-884. [CrossRef] [PubMed]

18. Huyut, Z.; Beydemir, S.; Gulcin, I. Inhibition properties of some flavonoids on carbonic anhydrase I and II isoenzymes purified from human erythrocytes. J. Biochem. Mol. Toxicol. 2017, 31, e21930. [CrossRef]

19. Gažák, R.; Marhol, P.; Purchartová, K.; Monti, D.; Biedermann, D.; Riva, S.; Cvak, L.; Křen, V. Large-scale separation of silybin diastereoisomers using lipases. Process Biochem. 2010, 45, 1657-1663. [CrossRef] 
20. Huang, D.; Ou, B.; Hampsch-Woodill, M.; Flanagan, J.A.; Prior, R.L. High-throughput assay of oxygen radical absorbance capacity (ORAC) using a multichannel liquid handling system coupled with a microplate fluorescence reader in 96-well format. J. Agric. Food Chem. 2002, 50, 4437-4444. [CrossRef]

21. Wolfe, K.L.; Liu, R.H. Cellular antioxidant activity (CAA) assay for assessing antioxidants, foods, and dietary supplements. J. Agric. Food Chem. 2007, 55, 8896-8907. [CrossRef]

22. Nanayakkara, A.K.; Follit, C.A.; Chen, G.; Williams, N.S.; Vogel, P.D.; Wise, J.G. Targeted inhibitors of P-glycoprotein increase chemotherapeutic-induced mortality of multidrug resistant tumor cells. Sci. Rep. 2018, 8, 967-984. [CrossRef]

23. Souček, P.; Anzenbacher, P.; Skoumalová, I.; Dvořák, M. Expression of cytochrome P450 genes in CD34+ hematopoietic stem and progenitor cells. Stem Cells 2005, 23, 1417-1422. [CrossRef]

24. Bustin, S.A.; Benes, V.; Garson, J.A.; Hellemans, J.; Huggett, J.; Kubista, M.; Mueller, R.; Nolan, T.; Pfaffl, M.W.; Shipley, G.L.; et al. The miqe guidelines: Minimum information for publication of quantitative real-time PCR experiments. Clin. Chem. 2009, 55, 611-622. [CrossRef]

25. Taleb, A.; Ahmad, K.A.; Ihsan, A.U.; Qu, J.; Lin, N.; Hezam, K.; Koju, N.; Hui, L.; Ding, Q.L. Antioxidant effects and mechanism of silymarin in oxidative stress induced cardiovascular diseases. Biomed. Pharmacother. 2018, 102, 689-698. [CrossRef]

26. Amorati, R.; Valgimigli, L. Advantages and limitations of common testing methods for antioxidants. Free Radic. Res. 2015, 49, 633-649. [CrossRef]

27. Becker, K.; Schroecksnadel, S.; Gostner, J.; Zaknun, C.; Schennach, H.; Überall, F.; Fuchs, D. Comparison of in vitro tests for antioxidant and immunomodulatory capacities of compounds. Phytomedicine 2014, 21, 164-171. [CrossRef]

28. Sersen, F.; Vencel, T.; Annus, J. Silymarin and its components scavenge phenylglyoxylic ketyl radicals. Fitoterapia 2006, 77, 525-529. [CrossRef]

29. Banaee, M.; Sureda, A.; Mirvaghefi, A.R.; Rafei, G.R. Effects of long-term silymarin oral supplementation on the blood biochemical profile of rainbow trout (Oncorhynchus mykiss). Fish Physiol. Biochem. 2011, 37, 885-896. [CrossRef]

30. Naso, L.G.; Ferrer, E.G.; Butenko, N.; Cavaco, I.; Lezama, L.; Rojo, T.; Etcheverry, S.B.; Williams, P.A.M. Antioxidant, DNA cleavage, and cellular effects of silibinin and a new oxovanadium(iv)/silibinin complex. J. Biol. Inorg. Chem. 2011, 16, 653-668. [CrossRef]

31. Gabrielová, E.; Křen, V.; Jabůrek, M.; Modrianský, M. Silymarin component 2,3-dehydrosilybin attenuates cardiomyocyte damage following hypoxia/reoxygenation by limiting oxidative stress. Physiol. Res. 2015, 64, 79-91.

32. Rong, Y.Z.; Wang, Z.W.; Wu, J.H.; Zhao, B. A theoretical study on cellular antioxidant activity of selected flavonoids. Spectrochim. Acta A 2012, 93, 235-239. [CrossRef]

33. Forman, H.J.; Davies, K.J.; Ursini, F. How do nutritional antioxidants really work: Nucleophilic tone and para-hormesis versus free radical scavenging in vivo. Free Radic. Biol. Med. 2014, 66, 24-35. [CrossRef]

34. Borges, F.F.V.; Silva, C.R.E.; Goes, W.M.; Godoy, F.R.; Franco, F.C.; Veras, J.H.; Bailao, E.; Silva, D.D.E.; Cardoso, C.G.; da Cruz, A.D.; et al. Protective effects of silymarin and silibinin against DNA damage in human blood cells. BioMed Res. Int. 2018. [CrossRef]

35. Weidmann, A.E. Dihydroquercetin: More than just an impurity? Eur. J. Pharmacol. 2012, 684, 19-26. [CrossRef]

36. Trouillas, P.; Marsal, P.; Svobodová, A.; Vostálová, J.; Gažák, R.; Hrbáč, J.; Sedmera, P.; Křen, V.; Lazzaroni, R.; Duroux, J.-L.; et al. Mechanism of the antioxidant action of silybin and 2,3-dehydrosilybin flavonolignans: A joint experimental and theoretical study. J. Phys. Chem. A 2008, 112, 1054-1063. [CrossRef]

37. Valentová, K.; Biedermann, D.; Křen, V. 2,3-Dehydroderivatives of silymarin flavonolignans: Prospective natural compounds for the prevention of chronic diseases. Proceedings 2019, 11, 21. [CrossRef]

38. Biedermann, D.; Moravcová, V.; Valentová, K.; Kuzma, M.; Petrásková, L.; Císařová, I.; Křen, V. Oxidation of flavonolignan silydianin to unexpected lactone-acid derivative. Phytochem. Lett. 2019, 30, 14-20. [CrossRef]

39. Esmaeil, N.; Anaraki, S.B.; Gharagozloo, M.; Moayedi, B. Silymarin impacts on immune system as an immunomodulator: One key for many locks. Int. Immunopharmacol. 2017, 50, 194-201. [CrossRef]

40. Gupta, O.P.; Sing, S.; Bani, S.; Sharma, N.; Malhotra, S.; Gupta, B.D.; Banerjee, S.K.; Handa, S.S. Anti-inflammatory and anti-arthritic activities of silymarin acting through inhibition of 5-lipoxygenase. Phytomedicine 2000, 7, 21-24. [CrossRef] 
41. Agarwal, R.; Agarwal, C.; Ichikawa, H.; Singh, R.P.; Aggarwal, B.B. Anticancer potential of silymarin: From bench to bed side. Anticancer Res. 2006, 26, 4457-4498.

42. Chambers, C.S.; Holečková, V.; Petrásková, L.; Biedermann, D.; Valentová, K.; Buchta, M.; Křen, V. The silymarin composition and why does it matter? Food Res. Int. 2017, 100, 339-353. [CrossRef]

43. Juráňová, J.; Aury-Landas, J.; Boumediene, K.; Bauge, C.; Biedermann, D.; Ulrichová, J.; Franková, J. Modulation of skin inflammatory response by active components of silymarin. Molecules 2019, $24,123$. [CrossRef]

44. Krashin, E.; Piekiełko-Witkowska, A.; Ellis, M.; Ashur-Fabian, O. Thyroid hormones and cancer: A comprehensive review of preclinical and clinical studies. Front. Endocrinol. 2019, 10, 59. [CrossRef]

45. Johannes, J.; Jayarama-Naidu, R.; Meyer, F.; Wirth, E.K.; Schweizer, U.; Schomburg, L.; Kohrle, J.; Renko, K. Silychristin, a flavonolignan derived from the milk thistle, is a potent inhibitor of the thyroid hormone transporter MCT8. Endocrinology 2016, 157, 1694-1701. [CrossRef]

46. Groeneweg, S.; van den Berge, A.; Meima, M.E.; Peeters, R.P.; Visser, T.J.; Visser, W.E. Effects of chemical chaperones on thyroid hormone transport by MCT8 mutants in patient-derived fibroblasts. Endocrinology 2018, 159, 1290-1302. [CrossRef]

47. Alevizopoulos, K.; Calogeropoulou, T.; Lang, F.; Stournaras, C. Na+/K+ ATPase inhibitors in cancer. Curr. Drug Targets 2014, 15, 988-1000. [CrossRef]

48. Kubala, M.; Čechová, P.; Geletičová, J.; Biler, M.; Štenclová, T.; Trouillas, P.; Biedermann, D. Flavonolignans as a novel class of sodium pump inhibitors. Front. Physiol. 2016, 7, 115. [CrossRef]

49. Chambers, C.S.; Viktorová, J.; Řehořová, K.; Biedermann, D.; Turková, L.; Macek, T.; Křen, V.; Valentová, K. Defying multidrug resistance! Modulation of related transporters by flavonoids and flavonolignans. J. Agric. Food Chem. 2019. [CrossRef]

50. Zhang, S.; Morris, M.E. Effects of the flavonoids biochanin A, morin, phloretin, and silymarin on P-glycoprotein-mediated transport. J. Pharmacol. Exp. Ther. 2003, 304, 1258-1267. [CrossRef]

51. Wu, J.W.; Lin, L.C.; Tsai, T.H. Drug-drug interactions of silymarin on the perspective of pharmacokinetics. J. Ethnopharmacol. 2009, 121, 185-193. [CrossRef]

52. Chung, S.Y.; Sung, M.K.; Kim, N.H.; Jang, J.O.; Go, E.J.; Lee, H.J. Inhibition of P-glycoprotein by natural products in human breast cancer cells. Arch. Pharm. Res. 2005, 28, 823-828. [CrossRef]

53. Džubák, P.; Hajdúch, M.; Gažák, R.; Svobodová, A.; Psotová, J.; Walterová, D.; Sedmera, P.; Křen, V. New derivatives of silybin and 2,3-dehydrosilybin and their cytotoxic and P-glycoprotein modulatory activity. Bioorg. Med. Chem. 2006, 14, 3793-3810. [CrossRef]

54. Sadava, D.; Kane, S.E. Silibinin reverses drug resistance in human small-cell lung carcinoma cells. Cancer Lett. 2013, 339, 102-106. [CrossRef]

55. Večeřa, R.; Zacharová, A.; Orolin, J.; Škottová, N.; Anzenbacher, P. The effect of silymarin on expression of selected ABC transporters in the rat. Vet. Med. 2011, 56, 59-62. [CrossRef] 